Part of Journal of Research of the National Bureau of Standards, Volume 20, January 1938

\title{
STRENGTH, WATER ABSORPTION, AND RESISTANCE TO FREEZING AND THAWING OF SAND-LIME BRICK
}

\author{
By John W. McBurney and Allan R. Eberle
}

\section{ABSTRACT}

The compressive and transverse strengths, water absorption, and penetrability of 120 specimens of sand-lime brick representing 11 plants were determined. Sieve analyses of sands from the same plants were also made. The same bricks were subjected to 50 cycles of freezing and thawing. It is concluded that resistance to freezing and thawing of sand-lime brick is estimated by strength when the bricks comply with the visual inspection clause of the American Society for Testing Materials' Specification for Sand-Lime Brick C 73-30.

\section{CONTENTS}

I. Introduction

II. Procedure and experimental data 68

1. Source and description of samples

2. Strength of bricks

3. Water absorption and penetrability 69

4. Sieve analysis of sands 70

5. Resistance to freezing and thawing 71

III. Discussion of data and conclusions

IV. Application of data to specification control of resistance to weathering- $\quad 75$

V. References_............ 76

\section{INTRODUCTION}

Since the publication of the results of McMurdie's survey of the properties of sand-lime brick $[1,2]^{1}$ the attention of investigators and specification writers has been increasingly directed to the question of durability of masonry units. As an illustration of this trend, the current tentative specification for clay building brick C 62-37' [3] abandons classifications based on strength and limits its grading to degrees of weather resistance. The investigation herein reported was undertaken therefore to determine the possibility of providing measures of the durability of sand-lime brick based upon correlation between physical properties and resistance to freezing and thawing.

1 Figures in brackets here and elsewhere in the text refer to the references at the end of this paper. 
Samples from 11 plants were selected in the present investigation (1936). Samples from 6 of these plants were selected by McMurdie [1] in 1928. The present paper, therefore, provides opportunity to compare the properties of bricks produced by these same six plants in 1928 and in 1936.

\section{PROCEDURE AND EXPERIMENTAL DATA}

\section{SOURCE AND DESCRIPTION OF SAMPLES}

Lots of 5 or 10 bricks each were selected from the 11 plants to give a representative range in quality of output from the principal brickproducing centers of the United States. Manufacturers $C, D, H$, and $K$ submitted lots representing more than one sample. Table 1 gives data on the size, weight, and density of the bricks. Only average values are given since the individual specimens from any one sample differed from the mean of the sample by only 0.05 inch in any dimension; the weight of the individual specimens in no case varied from the mean by more than 0.5 pound; and there was no apparent correlation between weight and other properties.

TABLE 1.-Average dimensions, weight, and density of sand-lime bricks

\begin{tabular}{|c|c|c|c|c|c|c|c|c|}
\hline \multirow{2}{*}{ Sample } & \multirow{2}{*}{$\begin{array}{l}\text { Number } \\
\text { of speci- } \\
\text { mens }{ }^{a}\end{array}$} & \multicolumn{3}{|c|}{ Brick dimensions } & \multirow{2}{*}{$\begin{array}{l}\text { Volume } \\
\text { of brick }\end{array}$} & \multirow{2}{*}{$\begin{array}{c}\text { Weight } \\
\text { per brick }\end{array}$} & \multirow{2}{*}{$\begin{array}{l}\text { Weight } \\
\text { per cubic } \\
\text { foot of } \\
\text { brick }\end{array}$} & \multirow{2}{*}{ Density } \\
\hline & & Length & Width & Depth & & & & \\
\hline $\begin{array}{l}A-\cdots \\
B \\
C 1 \\
C 2\end{array}$ & $\begin{array}{r}10 \\
10 \\
10 \\
5\end{array}$ & $\begin{array}{l}\text { in. } \\
8.00 \\
8.50 \\
8.02 \\
8.02\end{array}$ & $\begin{array}{l}\text { in. } \\
3.75 \\
3.94 \\
3.79 \\
3.79\end{array}$ & $\begin{array}{l}\text { in. } \\
2.26 \\
2.40 \\
2.30 \\
2.30\end{array}$ & $\begin{array}{l}\text { in. }{ }^{3} \\
67.9 \\
80.1 \\
69.9 \\
69.9\end{array}$ & $\begin{array}{l}\mathrm{lb} \\
4.28 \\
5.12 \\
4.85 \\
4.98\end{array}$ & $\begin{array}{l}\mathrm{lb} \\
108.8 \\
110.5 \\
119.6 \\
123.1\end{array}$ & $\begin{array}{rl}\mathrm{g} / \mathrm{ml} & 1.74 \\
1.77 \\
1.91 \\
1.97\end{array}$ \\
\hline$D 1$. & 5 & 8.05 & 3. 77 & 2. 27 & 68.9 & 4. 31 & 108.1 & 1. 73 \\
\hline $\begin{array}{l}D 2 \ldots \\
E- \\
F-\cdots\end{array}$ & $\begin{array}{r}5 \\
10 \\
10\end{array}$ & $\begin{array}{l}8.05 \\
8.02 \\
8.29\end{array}$ & $\begin{array}{l}3.78 \\
3.75 \\
3.76\end{array}$ & $\begin{array}{l}2.31 \\
2.26 \\
2.24\end{array}$ & $\begin{array}{l}70.3 \\
68.0 \\
70.0\end{array}$ & $\begin{array}{l}4.44 \\
4.25 \\
4.36\end{array}$ & $\begin{array}{l}109.1 \\
108.0 \\
107.6\end{array}$ & $\begin{array}{l}1.75 \\
1.73 \\
1.72\end{array}$ \\
\hline $\begin{array}{l}G \\
H 1 \\
H 2 \\
H \\
I\end{array}$ & $\begin{array}{r}10 \\
5 \\
5 \\
10\end{array}$ & $\begin{array}{l}8.05 \\
8.01 \\
8.00 \\
8.02\end{array}$ & $\begin{array}{l}3.75 \\
3.77 \\
3.75 \\
\text { 3. } 75\end{array}$ & $\begin{array}{l}2.34 \\
2.29 \\
2.27 \\
2.29\end{array}$ & $\begin{array}{l}70.5 \\
69.2 \\
68.5 \\
68.8\end{array}$ & $\begin{array}{l}4.78 \\
4.57 \\
4.60 \\
4.42\end{array}$ & $\begin{array}{l}117.2 \\
114.1 \\
116.0 \\
111.0\end{array}$ & $\begin{array}{l}1.88 \\
1.83 \\
1.86 \\
1.78\end{array}$ \\
\hline $\begin{array}{l}J_{1} \\
K{ }_{1}\end{array}$ & $\begin{array}{r}10 \\
5 \\
5 \\
5\end{array}$ & $\begin{array}{l}\text { 8. } 02 \\
8.30 \\
8.30 \\
8.30\end{array}$ & $\begin{array}{l}3.75 \\
4.05 \\
4.05 \\
4.04\end{array}$ & $\begin{array}{l}2.32 \\
2.35 \\
2.37 \\
2.37\end{array}$ & $\begin{array}{l}69.9 \\
79.0 \\
79.7 \\
79.5\end{array}$ & $\begin{array}{l}\text { 5. } 20 \\
\text { 5. } 14 \\
\text { 5. } 51 \\
\text { 5. } 24\end{array}$ & $\begin{array}{l}128.5 \\
112.4 \\
119.5 \\
113.9\end{array}$ & $\begin{array}{l}2.06 \\
1.80 \\
1.91 \\
1.82\end{array}$ \\
\hline $\begin{array}{l}\text { Average } \\
\text { specimens)... }\end{array}$ & & 8. 12 & 3.81 & 2.31 & 71.5 & 4. 72 & 114.1 & 1. 83 \\
\hline
\end{tabular}

a The number of specimens applies also to tables 2 and 3 .

\section{STRENGTH OF BRICKS}

Table 2 reports average values of the maximum and minimum strengths of the samples described in table 1. Where McMurdie reported tests from the same plants his data are given for comparison. 
TABLE 2.-Compressive strength (flatwise) and transverse strength of sand-lime brick

\begin{tabular}{|c|c|c|c|c|c|c|c|c|c|c|c|c|c|}
\hline \multirow{3}{*}{ Sample } & \multicolumn{7}{|c|}{ Compressive strength, flatwise $\left(1 \mathrm{~b} / \mathrm{in} .{ }^{2}\right)$} & \multicolumn{6}{|c|}{ Modulus of rupture (lb/in. $\left.{ }^{2}\right)$} \\
\hline & \multirow{2}{*}{$\underset{(a)}{\operatorname{avg}}$} & \multirow{2}{*}{$\max$} & \multirow{2}{*}{$\min$} & \multicolumn{3}{|c|}{ McMurdie } & \multirow{2}{*}{$\begin{array}{c}\text { avg } \\
(b)\end{array}$} & \multirow{2}{*}{$\max$} & \multirow{2}{*}{$\min$} & \multirow[b]{2}{*}{ avg } & \multicolumn{2}{|c|}{ McMurdie } & \multirow{2}{*}{$\underset{b / a}{\text { Ratio }}$} \\
\hline & & & & avg & $\max$ & $\min$ & & & & & $\max$ & $\min$ & \\
\hline $\begin{array}{l}A- \\
B_{-} \\
C 1 \\
C 2\end{array}$ & $\begin{array}{l}5,250 \\
4,100 \\
4,645 \\
5,370\end{array}$ & $\begin{array}{l}6,380 \\
4,560 \\
5,380 \\
6,180\end{array}$ & $\left.\begin{array}{l}4,630 \\
3,290 \\
3,345 \\
4,870\end{array}\right\}$ & $\left\{\begin{array}{r}3,880 \\
2,910\end{array}\right.$ & $\begin{array}{r}5,520 \\
3,260\end{array}$ & $\begin{array}{r}2,780 \\
2,440\end{array}$ & $\left\{\begin{array}{l}555 \\
660 \\
640 \\
760\end{array}\right.$ & $\begin{array}{l}700 \\
805 \\
750 \\
925\end{array}$ & $\begin{array}{l}425 \\
535 \\
565 \\
680\end{array}$ & $\begin{array}{r}615 \\
-620 \\
\end{array}$ & $\begin{array}{r}815 \\
\hdashline 965\end{array}$ & $\begin{array}{r}380 \\
-415\end{array}$ & $\left\{\begin{array}{l}0.11 \\
.16 \\
.14 \\
.14\end{array}\right.$ \\
\hline $\begin{array}{l}D 1 \\
D 2 \\
E \\
F \\
G\end{array}$ & $\begin{array}{l}3,400 \\
3,635 \\
5,135 \\
4,550 \\
4,180\end{array}$ & $\begin{array}{l}3,605 \\
3,785 \\
5,960 \\
5,370 \\
4,730\end{array}$ & \begin{tabular}{|}
3,250 \\
3,520 \\
4,300 \\
3,720 \\
3,250
\end{tabular} & $\begin{array}{l}2,810 \\
3,930\end{array}$ & $\begin{array}{r}- \\
3,860 \\
5,140\end{array}$ & $\begin{array}{r} \\
2,090 \\
2,680\end{array}$ & $\begin{array}{l}330 \\
485 \\
735 \\
565 \\
540\end{array}$ & $\begin{array}{l}380 \\
520 \\
865 \\
710 \\
605\end{array}$ & $\begin{array}{l}280 \\
460 \\
630 \\
455 \\
500\end{array}$ & $\begin{array}{l}600 \\
690\end{array}$ & $\begin{array}{r}860 \\
995\end{array}$ & $\begin{array}{r}275 \\
295\end{array}$ & $\begin{array}{l}.10 \\
.135 \\
.14 \\
.12 \\
.13\end{array}$ \\
\hline $\begin{array}{l}H 1 \\
H 2 \\
H 2_{-} \\
I_{-} \\
J_{-}\end{array}$ & $\begin{array}{l}4,705 \\
4,785 \\
5,210 \\
7,615\end{array}$ & $\begin{array}{l}5,105 \\
5,110 \\
6,040 \\
8,360\end{array}$ & $\begin{array}{l}4,075 \\
4,420 \\
4,270 \\
6,730\end{array}$ & 3,770 & 5,010 & $\begin{array}{r}2,620 \\
\hdashline\end{array}$ & $\left\{\begin{array}{l}530 \\
515 \\
620 \\
975\end{array}\right.$ & $\begin{array}{r}575 \\
580 \\
815 \\
1,125\end{array}$ & $\begin{array}{l}490 \\
400 \\
545 \\
870\end{array}$ & 550 & \begin{tabular}{c}
670 \\
\hdashline \\
\end{tabular} & \begin{tabular}{c}
455 \\
\hdashline \\
\end{tabular} & $\left\{\begin{array}{l}.11 \\
.11 \\
.12 \\
.13\end{array}\right.$ \\
\hline $\begin{array}{l}K 1 \\
K K^{3} \\
K^{3}\end{array}$ & $\begin{array}{l}3,620 \\
3,800 \\
3,235\end{array}$ & $\begin{array}{l}4,320 \\
5,590 \\
3,500\end{array}$ & $\begin{array}{l}3,260 \\
2,840 \\
2,950\end{array} \mid$ & $\{2,310$ & 3,730 & 1,260 & $\begin{array}{l}825 \\
797 \\
640\end{array}$ & $\begin{array}{l}925 \\
945 \\
755\end{array}$ & $\begin{array}{l}710 \\
692 \\
285\end{array}$ & 460 & 765 & 180 & $\left\{\begin{array}{l}.23 \\
.21 \\
.19\end{array}\right.$ \\
\hline $\begin{array}{l}\text { Average } \\
\text { Average for com- } \\
\text { parison with } \\
\text { M cM Murdie's } \\
\text { tests. }\end{array}$ & 4,480 & & & 3,270 & & & 643 & & & 589 & & & \\
\hline
\end{tabular}

The tests reported in table 2 were made according to the Standard Methods for Testing Brick [4] C 67-37 of the American Society for Testing Materials.

\section{WATER ABSORPTION AND PENETRABILITY}

Table 3 gives the percentage gain in weight after 24-hour cold immersion and after 5-hour boiling, and also the gain in weight (in grams) resulting from the partial immersion of whole brick flatwise in $1 / 8$ inch of water for 3 minutes. Washburn [5] defined penetrability as "the ease with which a liquid is drawn into the pores of the body by capillary suction, without attendant chemical action between the body and the liquid," and described a method of test for penetrability which consisted in determining the gain in weight resulting from partial immersion of the test specimen in water for a predetermined time. The term "rate of absorption" does not properly apply to a gain in weight resulting from partial immersion for 3 minutes since, obviously, one point does not determine a rate. This paper, therefore, following Washburn, uses the term "penetrability" instead of "rate of absorption." Since the range in absorption by immersion in no case exceeded the mean \pm 1.8 percent, maximum and minimum absorption values are not given. McMurdie's results for penetrability are omitted, because they represent 5 -minute partial immersion and hence are not directly comparable with the 3-minute tests. 
TABLE 3.-Water absorption and rate of absorption of sand-lime brick

\begin{tabular}{|c|c|c|c|c|c|c|c|c|}
\hline \multirow{3}{*}{ Sample } & \multicolumn{8}{|c|}{ Water absorption test } \\
\hline & \multicolumn{2}{|c|}{$\begin{array}{l}\text { 24-hour cold immer- } \\
\text { sion (average) }\end{array}$} & \multicolumn{2}{|c|}{$\begin{array}{l}\text { 5-hour boiling } \\
\text { (average) }\end{array}$} & \multirow{2}{*}{$\begin{array}{c}\text { Ratio } \\
C 24 / B 5\end{array}$} & \multicolumn{3}{|c|}{$\begin{array}{l}\text { Penetrability during 3-min. } \\
\text { of partial immersion in 1/8 in. } \\
\text { of water }\end{array}$} \\
\hline & $C 24$ & McMurdie & B5 & McMurdie & & A verage & $\begin{array}{l}\text { Maxi- } \\
\text { mum }\end{array}$ & $\begin{array}{l}\text { Mini- } \\
\text { mum }\end{array}$ \\
\hline $\begin{array}{l}A \\
B \\
C l_{-}\end{array}$ & $\begin{array}{l}\% \\
13.7 \\
12.9 \\
10.4 \\
10.0 \\
13.0\end{array}$ & $\begin{array}{c}\% \\
13.4 \\
14.0\end{array}$ & $\begin{array}{c}\% \\
18.4 \\
18.2 \\
14.7 \\
13.9 \\
18.7\end{array}$ & \begin{tabular}{c|}
$\%_{18.1}$ \\
18.8
\end{tabular} & $\begin{array}{l}\mathrm{g} \\
0.74 \\
.71 \\
.71 \\
.72 \\
.70\end{array}$ & $\begin{array}{l}\mathrm{g} \\
29.0 \\
93.5 \\
33.0 \\
22.3 \\
35.1\end{array}$ & $\begin{array}{r}\mathrm{g} \\
49.0 \\
143.0 \\
63.5 \\
27.5 \\
47.0\end{array}$ & $\begin{array}{l}\mathrm{g}_{21.0} \\
52.5 \\
22.0 \\
18.5 \\
26.5\end{array}$ \\
\hline $\begin{array}{l}D^{2} \\
E_{1} \\
F \\
G \\
H 1 \\
H 2\end{array}$ & $\begin{array}{r}13.5 \\
12.7 \\
11.8 \\
9.8 \\
11.6 \\
12.3\end{array}$ & $\begin{array}{l}15.9 \\
12.1 \\
11.8\end{array}$ & $\begin{array}{l}18.8 \\
18.5 \\
16.4 \\
14.8 \\
16.1 \\
15.7\end{array}$ & $\begin{array}{l}21.6 \\
17.0 \\
13.7\end{array}$ & $\begin{array}{l}.77 \\
.69 \\
.71 \\
.66 \\
.72 \\
.78\end{array}$ & $\begin{array}{l}73.7 \\
49.8 \\
36.2 \\
60.4 \\
31.7 \\
29.9\end{array}$ & $\begin{array}{r}102.0 \\
85.0 \\
70.0 \\
86.5 \\
37.5 \\
33.5\end{array}$ & $\begin{array}{l}38.5 \\
24.0 \\
21.5 \\
46.5 \\
27.5 \\
27.0\end{array}$ \\
\hline $\begin{array}{l}I_{1} \\
J_{1} 1 \\
K K^{2} \\
K\end{array}$ & $\begin{array}{r}13.1 \\
8.4 \\
12.2 \\
10.9 \\
12.1 \\
\end{array}$ & 15.7 & $\begin{array}{l}17.8 \\
10.3 \\
17.1 \\
14.0 \\
16.8\end{array}$ & 17.8 & $\begin{array}{l}.74 \\
.81 \\
.72 \\
.78 \\
.72\end{array}$ & $\begin{array}{r}14.2 \\
12.9 \\
105.4 \\
36.1 \\
71.6\end{array}$ & $\begin{array}{r}17.0 \\
15.0 \\
140.0 \\
47.0 \\
87.5\end{array}$ & $\begin{array}{r}12.0 \\
9.5 \\
77.5 \\
21.0 \\
60.0\end{array}$ \\
\hline A verage & 11.7 & $\cdots$ & 16.2 & 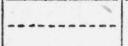 & 0.725 & 44.3 & & \\
\hline
\end{tabular}

Water absorption, like strength, was determined according to the American Society for Testing Materials Standard Methods for Testing Brick C 67-37.

\section{SIEVE ANALYSES OF SANDS}

Samples of sand were submitted by the same manufacturers that provided the bricks. Table 4 gives the results of sieve analyses of these sands. The wide range in grading is noteworthy. The percentage of sand by weight passing the No. 100 sieve ranged from 1 percent (sample $A$ ) to 51 percent (sample $I$ ). Sample $H$ is discussed in connection with the freezing and thawing results.

TABLE 4.-Sieve analyses of sands used in making sand-lime bricks

\begin{tabular}{|c|c|c|c|c|c|c|c|c|c|}
\hline \multirow{2}{*}{ Sample } & \multicolumn{9}{|c|}{ Percentage of sand passing sieve No.- } \\
\hline & $3 / 8$ & 4 & 8 & 16 & 30 & 40 & 50 & 80 & 100 \\
\hline $\begin{array}{l}A \\
B \\
B \\
C\end{array}$ & $\begin{array}{l}\% \\
100 \\
100 \\
100 \\
100\end{array}$ & $\begin{array}{l}\% \\
100 \\
100 \\
100 \\
100\end{array}$ & $\begin{array}{r}\% \\
100 \\
99 \\
100 \\
100\end{array}$ & $\begin{array}{r}\% \\
100 \\
98 \\
98 \\
96\end{array}$ & $\begin{array}{c}\% \\
99 \\
93 \\
89 \\
94\end{array}$ & $\begin{array}{r}\% \\
95 \\
80 \\
77 \\
88\end{array}$ & $\begin{array}{l}\% \\
51 \\
40 \\
59 \\
65\end{array}$ & $\begin{array}{r}\% \\
6 \\
5 \\
28 \\
20\end{array}$ & $\begin{array}{r}\% \\
1 \\
2 \\
20 \\
12\end{array}$ \\
\hline $\begin{array}{l}E-1 \\
F \\
G \\
H\end{array}$ & $\begin{array}{r}100 \\
100 \\
100 \\
99\end{array}$ & $\begin{array}{r}100 \\
100 \\
100 \\
97\end{array}$ & $\begin{array}{r}100 \\
99 \\
100 \\
95\end{array}$ & $\begin{array}{r}100 \\
99 \\
100 \\
94\end{array}$ & $\begin{array}{r}99 \\
98 \\
100 \\
91\end{array}$ & $\begin{array}{l}96 \\
94 \\
94 \\
82\end{array}$ & $\begin{array}{l}79 \\
72 \\
71 \\
65\end{array}$ & $\begin{array}{l}15 \\
22 \\
21 \\
25\end{array}$ & $\begin{array}{r}5 \\
14 \\
12 \\
15\end{array}$ \\
\hline$I_{J}$ & $\begin{array}{l}100 \\
100 \\
100\end{array}$ & $\begin{array}{r}100 \\
100 \\
98\end{array}$ & $\begin{array}{r}100 \\
100 \\
98\end{array}$ & $\begin{array}{r}100 \\
99 \\
97\end{array}$ & $\begin{array}{l}99 \\
98 \\
97\end{array}$ & $\begin{array}{l}98 \\
95 \\
96\end{array}$ & $\begin{array}{l}91 \\
82 \\
84\end{array}$ & $\begin{array}{l}62 \\
45 \\
36\end{array}$ & $\begin{array}{r}51 \\
34 \\
4\end{array}$ \\
\hline
\end{tabular}




\section{RESISTANCE TO FREEZING AND THAWING}

Each specimen, as a half brick, was subjected to 50 cycles of freezing and thawing by the following method. The oven-dried bricks were weighed, totally immersed in water at room temperature for 4 hours and subjected to freezing for 20 hours standing on edge in $1 / 2$ inch of water. Thawing was accomplished by total immersion in water at room temperature for 4 hours. After each fifth cycle of freezing and thawing, the bricks were stored in air for 44 hours, then totally immersed for 4 hours before starting another set of 5 cycles of freezing and thawing. After 25 cycles the specimens were oven-dried and weighed, and again oven-dried and weighed after 50 cycles.

This method differs from that used by McMurdie [2] principally in that McMurdie used a longer period of total immersion and permitted absorption to increase. From comparative tests on clay brick, it is concluded that McMurdie's method produces more rapid disintegration than the method described in this paper.

After completing 50 cycles of freezing and thawing, the compressive strength, flatwise, was determined on all the surviving bricks for comparison with the compressive strength on the other halves, which had been previously tested.

Table 5 summarizes the freezing and thawing data. 
TABLE 5.-Results of freezing and thawing of sand-lime bricks

\begin{tabular}{|c|c|c|c|c|c|c|c|c|c|c|c|c|c|c|}
\hline \multirow{2}{*}{ Sample } & \multirow{2}{*}{$\begin{array}{l}\text { Number } \\
\text { of speci- } \\
\text { mens }\end{array}$} & \multicolumn{3}{|c|}{ Loss in weight after 25 cycles } & \multicolumn{2}{|c|}{$\begin{array}{l}\text { Number of speci- } \\
\text { mens rejected }\end{array}$} & \multicolumn{3}{|c|}{ Loss in weight after 50 cycles } & \multicolumn{2}{|c|}{$\begin{array}{l}\text { Number of speci- } \\
\text { mens rejected }\end{array}$} & \multicolumn{3}{|c|}{$\begin{array}{l}\text { Gain or loss in compressive } \\
\text { strength }\end{array}$} \\
\hline & & avg & $\max$ & $\min$ & $\begin{array}{c}3 \text { percent } \\
\text { loss }\end{array}$ & $\begin{array}{l}10 \text { percent } \\
\text { loss }\end{array}$ & avg & $\max$ & $\min$ & $\begin{array}{c}3 \text { percent } \\
\text { loss }\end{array}$ & $\begin{array}{c}10 \text { percent } \\
\text { loss }\end{array}$ & avg & $\max$ & $\min$ \\
\hline $\begin{array}{l}A \\
B \\
B \\
C 2\end{array}$ & $\begin{array}{r}10 \\
10 \\
10 \\
5\end{array}$ & $\begin{array}{c}\% \\
0.38 \\
.07 \\
.08 \\
.10\end{array}$ & $\begin{array}{c}\% \\
2.20 \\
0.21 \\
.37 \\
.14\end{array}$ & $\begin{array}{r}\% \\
0.00 \\
.00 \\
.00 \\
.05\end{array}$ & $\begin{array}{l}0 \\
0 \\
0 \\
0\end{array}$ & $\begin{array}{l}0 \\
0 \\
0 \\
0\end{array}$ & $\begin{array}{l}\% \\
0.82 \\
.41 \\
.26 \\
.10\end{array}$ & $\begin{array}{r}\% \\
4.68 \\
0.92 \\
.54 \\
.14\end{array}$ & $\begin{array}{c}\% \\
0.00 \\
.09 \\
.05 \\
.05\end{array}$ & $\begin{array}{l}1 \\
0 \\
0 \\
0\end{array}$ & $\begin{array}{l}0 \\
0 \\
0 \\
0\end{array}$ & $\begin{array}{l}\% \\
-11.0 \\
-0.7 \\
+15.1 \\
+16.5\end{array}$ & $\begin{array}{l}\% \\
+10.9 \\
+8.0 \\
+21.9 \\
+36.2\end{array}$ & $\begin{array}{l}\% \\
-21.6 \\
-12.4 \\
-6.1 \\
+3.4\end{array}$ \\
\hline $\begin{array}{l}D 1 \\
D 2 \\
E \\
F \\
F\end{array}$ & $\begin{array}{r}5 \\
5 \\
10 \\
10\end{array}$ & $\begin{array}{r}1.90 \\
0.14 \\
.10 \\
.12\end{array}$ & $\begin{array}{l}3.65 \\
0.40 \\
.32 \\
.35\end{array}$ & $\begin{array}{l}.82 \\
.05 \\
.00 \\
.00\end{array}$ & $\begin{array}{l}1 \\
0 \\
0 \\
0\end{array}$ & $\begin{array}{l}0 \\
0 \\
0 \\
0\end{array}$ & $\begin{array}{r}4.68 \\
0.45 \\
.23 \\
.41\end{array}$ & $\begin{array}{l}7.18 \\
1.31 \\
0.54 \\
1.65\end{array}$ & $\begin{array}{r}2.09 \\
0.10 \\
.00 \\
.00\end{array}$ & $\begin{array}{l}3 \\
0 \\
0 \\
0\end{array}$ & $\begin{array}{l}0 \\
0 \\
0 \\
0\end{array}$ & $\begin{array}{r}-18.7 \\
-9.0 \\
-8.9 \\
-32.4\end{array}$ & $\begin{array}{r}-5.9 \\
+2.7 \\
+0.6 \\
-15.6\end{array}$ & $\begin{array}{l}-38.6 \\
-24.2 \\
-23.6 \\
-40.3\end{array}$ \\
\hline $\begin{array}{ll}G \\
H 1_{2}\end{array}$ & $\begin{array}{r}10 \\
5 \\
5 \\
10\end{array}$ & $\begin{array}{r}.14 \\
.63 \\
2.16 \\
0.04\end{array}$ & $\begin{array}{r}.32 \\
.92 \\
6.56 \\
0.11\end{array}$ & $\begin{array}{l}.00 \\
.30 \\
.29 \\
.00\end{array}$ & $\begin{array}{l}0 \\
0 \\
1 \\
0\end{array}$ & $\begin{array}{l}0 \\
0 \\
0 \\
0\end{array}$ & $\begin{array}{r}.60 \\
2.14 \\
\times 8.0+ \\
0.28\end{array}$ & $\begin{array}{r}1.65 \\
3.31 \\
>10.0 \\
0.53\end{array}$ & $\begin{array}{r}.14 \\
.60 \\
2.12 \\
0.11\end{array}$ & $\begin{array}{l}0 \\
2 \\
4 \\
0\end{array}$ & $\begin{array}{l}0 \\
0 \\
3 \\
0\end{array}$ & $\begin{array}{r}0.0 \\
-11.6 \\
-70.0 \\
-10.7\end{array}$ & $\begin{array}{r}+14.1 \\
-6.3 \\
-13.3 \\
+9.6\end{array}$ & $\begin{array}{r}-9.0 \\
-17.6 \\
-100.0 \\
-26.0\end{array}$ \\
\hline $\begin{array}{l}J_{1} \\
K 1 \\
K{ }_{1} \\
K_{3}\end{array}$ & $\begin{array}{r}10 \\
5 \\
5 \\
5\end{array}$ & $\begin{array}{l}.05 \\
.68 \\
.17 \\
.33\end{array}$ & $\begin{array}{r}.23 \\
2.82 \\
0.33 \\
.53 \\
\end{array}$ & $\begin{array}{l}.00 \\
.05 \\
.09 \\
.14 \\
\end{array}$ & $\begin{array}{l}0 \\
0 \\
0 \\
0\end{array}$ & $\begin{array}{l}0 \\
0 \\
0 \\
0\end{array}$ & $\begin{array}{r}.14 \\
2.02 \\
0.40 \\
.58\end{array}$ & $\begin{array}{l}.21 \\
5.97 \\
1.16 \\
1.10\end{array}$ & $\begin{array}{l}.00 \\
.23 \\
.00 \\
.33\end{array}$ & $\begin{array}{l}0 \\
1 \\
0 \\
0\end{array}$ & $\begin{array}{l}0 \\
0 \\
0 \\
0\end{array}$ & $\begin{array}{r}+20.9 \\
0.0 \\
+9.4 \\
+0.9\end{array}$ & $\begin{array}{r}+44.5 \\
+21.1 \\
+44.0 \\
+7.2\end{array}$ & $\begin{array}{r}+11.7 \\
-12.4 \\
-21.2 \\
-6.4\end{array}$ \\
\hline All specimens.......-. & 120 &.- & 6.56 & 0.00 & 2 & 0 & $\cdots$ & $>10.0$ & 0.00 & 11 & 3 & in & 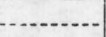 & - \\
\hline
\end{tabular}

Average includes 3 specimens with losses greater than 10 percent.

- Zero strength was ascribed to the 3 specimens that failed. 


\section{DISCUSSION OF DATA AND CONCLUSIONS}

From the data presented in the preceding section the following conclusions appear justified:

1. The bricks produced by a given manufacturer are quite uniform in size. The American Society for Testing Materials' standard size for sand-lime brick [5] (21/4 by $3 \frac{3}{4}$ by 8 inches with a permissible variation of $\pm 1 / 16$ inch in depth, $\pm 1 / 8$ inch in width, and $\pm 1 / 4$ inch in length) is complied with, except for samples $B$ and $K$ in all dimensions and samples $G$ and $J$ in depth. Simplified Practice Recommendation R38-37 for sand-lime brick conforms to the American Society for Testing Materials' standard for size, except that the tolerance is $\pm 1 / 8$ inch instead of $\pm 1 / 16$ inch. This increased tolerance admits samples $G$ and $J$.

2. The ratio of modulus of rupture to compressive strength ranges from 0.10 to 0.23 ; therefore, any prediction of one measure of strength from the other is subject to large error. The corresponding ratios on samples from the same plants previously tested by McMurdie are, in general, higher. The moduli of rupture are in fair agreement for the two series of tests, but the compressive strengths of the current series are notably higher.

3. McMurdie [1] reported for six plants an average compressive strength of $3,270 \mathrm{lb} / \mathrm{in}^{2}$. Samples from the same six plants in 1936 averaged $4,480 \mathrm{lb} / \mathrm{in}^{2}$. As the water absorption by 5 -hour boiling was 17.8 percent for the 1928 samples and 15.9 percent for the 1936 samples, it is concluded that the gain in strength is actual and not due to differences in testing technique. Other things being equal, a decrease in water absorption is associated with an increase in strength. The two samples $A$ and $H$, which show a marked increase in compressive strength without a corresponding decrease in water absorption, may have been subjected to increased time and temperature of steaming. It is reported that such a change in manufacturing method was made by several plants following the publication of McMurdie's results.

4. The ratio of water absorption cold to water abosrption by 5-hour boiling is unrelated to resistance to freezing and thawing of sand-lime bricks. This confirms the conclusion of McMurdie.

5. Contrary to the conclusions of McMurdie, there does not appear to be a consistent relation between the penetrability and resistance to freezing and thawing of sand-lime bricks.

6. Neither water absorption by cold immersion nor by 5-hour boiling is related to resistance to freezing and thawing according to the results of the present tests, thus confirming the results of McMurdie [2] for different makes of brick.

7. Confirming the conclusion previously reported by McMurdie, good correlation with resistance to freezing and thawing is given by the compressive strengths. Table 6 is a rearrangement of the data for the purpose of showing the relation between compressive strength and the results of 50 cycles of freezing and thawing. 
TABLE 6.-Results of 50 cycles of freezing and thawing, classified according to compressive strength (half-bricks flatwise) of specimens

[Samples $H 1$ and $H 2$ omitted]

\begin{tabular}{|c|c|c|c|c|c|c|}
\hline \multirow{2}{*}{$\begin{array}{l}\text { Range in } \\
\text { compressive } \\
\text { strength }\end{array}$} & \multirow{2}{*}{$\begin{array}{l}\text { Num- } \\
\text { ber of } \\
\text { speci- } \\
\text { mens }\end{array}$} & \multirow{2}{*}{$\begin{array}{l}\text { Average } \\
\text { modulus } \\
\text { of } \\
\text { rupture }\end{array}$} & \multirow{2}{*}{$\begin{array}{l}\text { Original } \\
\text { compres- } \\
\text { sive } \\
\text { strength }\end{array}$} & \multirow{2}{*}{$\begin{array}{c}\text { A verage } \\
\text { change in } \\
\text { compressive } \\
\text { strength } \\
\text { after } \\
50 \text { cycles }\end{array}$} & \multicolumn{2}{|c|}{$\begin{array}{l}\text { Loss in weight } \\
\text { after } 50 \text { cycles }\end{array}$} \\
\hline & & & & & A verage & $\begin{array}{l}\text { Maxi- } \\
\text { mum }\end{array}$ \\
\hline $\begin{array}{c}\mathrm{Lb} / \mathrm{in} .^{2} \\
8,001 \text { to } 8,360 \\
7,501 \text { to } 8,000 \\
7,001 \text { to } 7,500 \\
6,501 \text { to } 7,000\end{array}$ & $\begin{array}{l}3 \\
3 \\
2 \\
2\end{array}$ & $\begin{array}{c}\text { Lb/in. }{ }^{2} \\
940 \\
990 \\
965 \\
1,015\end{array}$ & $\begin{array}{c}\text { Average } \\
\text { lb/in. } \\
8,300 \\
7,720 \\
7,310 \\
6,735\end{array}$ & $\begin{array}{l}\text { Percent } \\
+20.5 \\
+23.2 \\
+26.7 \\
+42.4\end{array}$ & $\begin{array}{c}\text { Percent } \\
0.15 \\
.11 \\
.11 \\
.20\end{array}$ & $\begin{array}{c}\text { Percent } \\
0.18 \\
.18 \\
.14 \\
.21\end{array}$ \\
\hline $\begin{array}{l}6,001 \text { to } 6,500 \\
5,501 \text { to } 6,000 \\
5,001 \text { to } 5,500 \\
\mathbf{4}, 501 \text { to } 5,000\end{array}$ & $\begin{array}{r}4 \\
8 \\
16 \\
20\end{array}$ & $\begin{array}{l}615 \\
690 \\
680 \\
620\end{array}$ & $\begin{array}{l}6,150 \\
5,690 \\
5,310 \\
4,740\end{array}$ & $\begin{array}{r}-11.6 \\
-14.6 \\
-5.1 \\
-3.7\end{array}$ & $\begin{array}{l}.23 \\
.29 \\
.27 \\
.24\end{array}$ & $\begin{array}{l}.40 \\
1.11 \\
1.14 \\
0.62\end{array}$ \\
\hline $\begin{array}{l}4,001 \text { to } 4,500 \\
3,501 \text { to } 4,000 \\
3,001 \text { to } 3,500 \\
2,840 \text { to } 3,000\end{array}$ & $\begin{array}{r}18 \\
17 \\
13 \\
4\end{array}$ & $\begin{array}{l}615 \\
590 \\
565 \\
585\end{array}$ & $\begin{array}{l}4,310 \\
3,740 \\
3,365 \\
2,930\end{array}$ & $\begin{array}{l}-3.3 \\
-2.8 \\
-3.0 \\
+6.2\end{array}$ & $\begin{array}{r}.45 \\
1.03 \\
2.33 \\
0.82\end{array}$ & $\begin{array}{l}1.65 \\
4.68 \\
7.18 \\
1.16\end{array}$ \\
\hline
\end{tabular}

8. The results of the freezing and thawing tests are classified in table 7 according to modulus of rupture.

The correlation between modulus of rupture and change in compressive strength after 50 cycles of freezing and thawing is excellent. The relation between modulus of rupture and loss in weight after 50 cycles is somewhat more consistent than the relation of compressive strength to loss in weight given in table 6 . Of the 10 specimens included in samples $H 1$ and H2, 8 fell in the grouping 501 to 600 $\mathrm{lb} / \mathrm{in} .^{2}$ for modulus of rupture and 2 in the grouping 401 to $500 \mathrm{lb} / \mathrm{in} .^{2}$.

TABLE 7.-Results of 50 cycles of freezing and thawing, classified according to modulus of rupture of specimens

[Samples $H 1$ and $H 2$ omitted]

\begin{tabular}{|c|c|c|c|c|c|c|}
\hline \multirow{2}{*}{$\begin{array}{l}\text { Range in } \\
\text { modulus of } \\
\text { rupture }\end{array}$} & \multirow{2}{*}{$\begin{array}{l}\text { Num- } \\
\text { ber of } \\
\text { speci- } \\
\text { mens }\end{array}$} & \multirow{2}{*}{$\begin{array}{c}\text { Average } \\
\text { modulus } \\
\text { of } \\
\text { rupture }\end{array}$} & \multirow{2}{*}{$\begin{array}{c}\text { Original } \\
\text { compres- } \\
\text { sive } \\
\text { strength } \\
50 \text { cycles }\end{array}$} & \multirow{2}{*}{$\begin{array}{l}\text { A verage } \\
\text { change in } \\
\text { compres- } \\
\text { sive } \\
\text { strength } \\
\text { after } \\
50 \text { cycles }\end{array}$} & \multicolumn{2}{|c|}{$\begin{array}{l}\text { Loss in weight } \\
\text { after } 50 \text { cycles }\end{array}$} \\
\hline & & & & & A verage & $\begin{array}{l}\text { Maxi- } \\
\text { mum }\end{array}$ \\
\hline $\begin{array}{c}\mathrm{Lb} / \mathrm{in} .^{2} \\
1,001 \text { to } 1,123 \\
901 \text { to } 1,000 \\
801 \text { to } 900 \\
701 \text { to } 800 \\
601 \text { to } 700\end{array}$ & $\begin{array}{r}3 \\
8 \\
11 \\
18 \\
27\end{array}$ & $\begin{array}{c}\mathrm{Lb} / \mathrm{in} .^{2} \\
1,064 \\
952 \\
839 \\
734 \\
644\end{array}$ & $\begin{array}{c}\text { Average } \\
\text { lb/in.2 } \\
7,535 \\
6,425 \\
5,310 \\
4,500 \\
4,745\end{array}$ & $\begin{array}{c}\text { Percent } \\
+31.2 \\
+22.5 \\
+5.8 \\
-1.7 \\
+1.1\end{array}$ & $\begin{array}{c}\text { Percent } \\
0.13 \\
.24 \\
.42 \\
.64 \\
.29\end{array}$ & $\begin{array}{c}\text { Percent } \\
0.21 \\
1.23 \\
2.98 \\
5.97 \\
1.14\end{array}$ \\
\hline $\begin{array}{l}501 \text { to } 600 \\
401 \text { to } 500 \\
301 \text { to } 400 \\
281 \text { to } 300\end{array}$ & $\begin{array}{r}28 \\
8 \\
3 \\
4\end{array}$ & $\begin{array}{l}547 \\
461 \\
361 \\
288\end{array}$ & $\begin{array}{l}3,735 \\
3,815 \\
3,300 \\
3,895\end{array}$ & $\begin{array}{r}-9.8 \\
-14.6 \\
-15.9 \\
-19.8\end{array}$ & $\begin{array}{l}.45 \\
1.08 \\
4.80 \\
2.80\end{array}$ & $\begin{array}{l}1.65 \\
4.68 \\
7.18 \\
5.88\end{array}$ \\
\hline
\end{tabular}

9. The sample of sand representing that used in manufacturing samples $H 1$ and $H_{2}$ contained clay balls retained on a $3 / 8$-inch sieve. Five percent by weight of this sample failed to pass a No. 8 sieve. It is considered that the lack of resistance to freezing and thawing: shown by samples $H 1$ and $H^{2}$ (see table 5) is explained by this peculiarity of the sand. 
10. Freezing and thawing produced a marked increase in strength where the brick possessed high strength originally. McMurdie [2] also observed an increase in strength as did Kirkpatrick and Palmer [7] and Peppel [8].

11. Of the 120 specimens tested, 50 cycles of freezing and thawing would cause rejection of 11 specimens, if 3.0 -percent loss of weight is taken as the criterion. The requirement of not exceeding 10-percent loss in weight would have rejected 3 specimens. The comparable samples tested by McMurdie gave a much higher incidence of failure. This is, in part, explained by the assumption that the method of freezing and thawing used in the present investigation is less severe, and in part, by the conclusion based upon strength and absorption data that the 1936 series of test specimens were of better quality.

On the basis of certain comparisons made with comparable samples of clay brick, it is considered that the method used in the present investigation corresponds in severity to that used by McBurney and Lovewell [9] in their investigation of the resistance to weathering of clay and shale brick.

\section{APPLICATION OF DATA TO SPECIFICATION CONTROL OF RESISTANCE TO WEATHERING}

The Standard Specifications for Sand-Lime Building Brick C73-30 [5] classify sand-lime brick into three grades as shown in table 8 .

TABLE 8

\begin{tabular}{|c|c|c|c|c|}
\hline \multirow{2}{*}{ Grade } & \multicolumn{2}{|c|}{$\begin{array}{l}\text { Compressive strength (bricks flatwise) } \\
\text { mean gross area }\end{array}$} & \multicolumn{2}{|c|}{$\begin{array}{l}\text { Modulus of rupture (bricks flatwise) } \\
\text { sross area }\end{array}$} \\
\hline & Mean of 5 tests & $\begin{array}{l}\text { Individual } \\
\text { minimum }\end{array}$ & Mean of 5 tests & $\begin{array}{l}\text { Individual } \\
\text { minimum }\end{array}$ \\
\hline $\begin{array}{l}A \\
B \\
C\end{array}$ & $\begin{array}{l}\text { lb/in. }{ }^{2} \\
4,500 \text { or over } \ldots \ldots \\
2,500 \text { to } 4,500 \ldots \\
1,250 \text { to } 2,500 \ldots \ldots\end{array}$ & $\begin{array}{l}\mathrm{lb} / \mathrm{in} .{ }^{2} \\
3,500 \\
2,000 \\
1,000\end{array}$ & \begin{tabular}{|l|}
600 or over $\mathrm{lb} / \mathrm{in} .^{2}$ \\
450 or over \\
300 or over
\end{tabular} & $\begin{array}{r}\mathrm{lb} / \mathrm{in} .^{2} \\
400 \\
300 \\
200\end{array}$ \\
\hline
\end{tabular}

A note is appended to this classification, which reads: "The above classifications are based on strength and do not necessarily measure weather resistance."

If the "individual minimum" in this classification is disregarded, the 120 bricks tested in this survey distribute, as shown in the third column of table 9, under the heading "Number of specimens."

The criterion "not more than 3.0-percent loss in weight or not more than 25.0-percent loss in strength" for passing 50 cycles of freezing and thawing is, in part, that used by McBurney and Lovewell ${ }^{9}$ in their rating of clay and shale bricks. The justification for the more severe requirement "not more than 1.0-percent loss" is that the the majority of sand-lime brick show a progressive loss in weight with increasing number of cycles of freezing and thawing. For clay and shale brick, with the exception of certain soft-mud specimens, failure takes place suddenly and completely. The choice of 1-, 3-, 10-, or even 100-percent loss in weight as the criterion of failure after a given number of cycles would little affect the ratings of many clay and shale bricks. The purpose of the 1.0-percent loss in weight maximum for sand-lime brick is to insure that the rate of disintegration is negligible. 
TABLE 9.-Classification of results of 50 cycles of freezing and thawing according to American Society for Testing Materials grading (120 specimens)

\begin{tabular}{|c|c|c|c|c|c|c|}
\hline \multicolumn{2}{|l|}{ Grading of brick } & \multirow[t]{2}{*}{$\begin{array}{c}\text { Number } \\
\text { of speci- } \\
\text { mens }\end{array}$} & \multicolumn{2}{|c|}{$\begin{array}{l}\text { Not more than 3.0- } \\
\text { percent loss in } \\
\text { weight, or not } \\
\text { more ciun } 25.0- \\
\text { percent loss in } \\
\text { com pres i v e } \\
\text { strength }\end{array}$} & \multicolumn{2}{|c|}{$\begin{array}{l}\text { Not more than } 1.0- \\
\text { percent loss in } \\
\text { weight, or not } \\
\text { more than } 25.0- \\
\text { percent loss in } \\
\text { c o m press iv } \\
\text { strength }\end{array}$} \\
\hline Compressive strength & $\begin{array}{c}\text { Modulus } \\
\text { of } \\
\text { rupture }\end{array}$ & & $\begin{array}{l}\text { Speci- } \\
\text { mens } \\
\text { passed }\end{array}$ & $\begin{array}{l}\text { Speci- } \\
\text { mens } \\
\text { failed }\end{array}$ & $\begin{array}{l}\text { Speci- } \\
\text { mens } \\
\text { passed }\end{array}$ & $\begin{array}{l}\text { Speci- } \\
\text { mens } \\
\text { failed }\end{array}$ \\
\hline & $\begin{array}{l}A \\
A\end{array}$ & $\begin{array}{l}43 \\
23\end{array}$ & $\begin{array}{r}\text { Number } \\
42 \\
21\end{array}$ & $\begin{array}{r}\text { Number } \\
1 \\
2\end{array}$ & $\begin{array}{r}\text { Number } \\
41 \\
18\end{array}$ & $\begin{array}{r}\text { Number } \\
2 \\
5\end{array}$ \\
\hline$A$ & $\begin{array}{l}B \\
B\end{array}$ & $\begin{array}{l}21 \\
27\end{array}$ & $\begin{array}{l}10 \\
22\end{array}$ & $\begin{array}{r}11 \\
5\end{array}$ & $\begin{array}{r}9 \\
18\end{array}$ & $\begin{array}{r}12 \\
9\end{array}$ \\
\hline$A$ & $\stackrel{C}{C}$ & $\frac{1}{5}$ & $\begin{array}{l}0 \\
2\end{array}$ & $\begin{array}{l}1 \\
3\end{array}$ & $\begin{array}{l}0 \\
0\end{array}$ & $\begin{array}{l}1 \\
5\end{array}$ \\
\hline
\end{tabular}

According to table 9 , it appears that sand-lime bricks, grading $A$ in both compressive strength and modulus of rupture, have a high probability of successfully withstanding 50 cycles of freezing and thawing by the method described in this paper. These data further indicate that a high transverse strength is more desirable than a high compressive strength for insuring resistance to frost action, if the two strengths are not in agreement. However, the poor showing of the $A$ (compressive strength) $B$ (modulus of rupture) combination is due to the fact that this classification included the $H 1$ and $H_{2}$ samples, which should be rejected under the "Inspection and Rejection" clause of the specification, which reads, in part, as follows:

"They shall be sound, of compact structure, reasonably uniform in shape and free from cracks, warpage, large pebbles, balls of clay [italics authors'] or particles of lime that would affect their serviceability or strength."

If this inspection and rejection clause can be made quantitative and enforceable, the $A, B$, and $C$ grades of the sand-lime-brick specification $\mathrm{C}$ 73-30 could be regarded as equivalent in weather resistance to the $S W, M W$, and $N W$ grades, respectively, of the Tentative Specifications for Building Brick (Made from Clay or Shale) C 62-37T [3] of the American Society for Testing Materials.

\section{REFERENCES}

[1] H.F. McMurdie. The absorption and strength of commercial sand-lime brick, Proc. Sand-Lime Brick Assn. (1930); also Rock Products 32, No. 24, 67 (1929).

[2] H. F. McMurdie. Results of freezing and thawing tests of sand-lime brick, Rock Products 34, No. 12, 53 (1931).

[3] Tentative specifications for building brick (made from clay or shale) C62-37T, Proc. Am. Soc. Testing Materials 3\%, part 1 (1937).

[4] Standard methods for testing brick, Proc. Am. Soc. Testing Materials 3\%, part 1, - (1937).

[5] Standard specifications for sand-lime building brick, C73-30, Am. Soc. Testing Materials Book of Standards, part 2, p. 123 (1936).

[6] E. W. Washburn. Porosity and the mechanism of absorption, J. Am. Ceramic Soc. 4, 920 (1921).

[7] H. A. Kirkpatrick and J. S. Palmer. Evidence of the durability of sand-lime brick, Proc. Sand-Lime Brick Assn. (1918).

[8] S. V. Peppel. Manufacture of Artificial Sandstone or Sand-Lime Brick, Bul. 5, Ohio Geol. Survey (1905).

[9] J. W. McBurney and C. E. Lovewell. Strength, water absorption, and weather resistance of building brick produced in the United States, Proc. Am. Soc. Testing Materials 33, part 2, 636 (1933).

Washington, October 15, 1937. 